\title{
Corporate Board and the Value of Diversified Public Listed Companies in Malaysia
}

\author{
Umar Salisu \\ Zuaini Ishak \\ Norfaiezah Sawandi \\ Universiti Utara Malaysia, Malaysia
}

\begin{abstract}
Key words
Corporate board, firm value, diversification, Public listed companies.
\end{abstract}

\begin{abstract}
This study examines the relationship between corporate board and firm value of diversified companies listed on Bursa Malaysia. It applies a multiple regression analysis on data collected from annual reports of the companies for the year 2017. The corporate board variables considered are board size, tenure of independence directors and the existence of risk management committee, while the value of firm is measured based on excess value. The results reveal that there is a negative relationship between tenure of independent directors, board size with firm value, while risk management committee maintains significant positive relationship with firm value. The study is supportive of the view that enhanced corporate governance practices contributes towards increasing firm value. Generally, this study provides new/additional insights for policy makers or regulators in improving the corporate governance policies in the future and main help in increasing understanding on the relationship between corporate governance practices and firm's value.
\end{abstract}

Corresponding author: Umar Salisu

Email addresses for the corresponding author: umarsalisu2005@gmail.com

First submission received: $14^{\text {th }}$ July 2018

Revised submission received: $19^{\text {th }}$ October 2018

Accepted: $1^{\text {st }}$ November 2018

\section{Introduction}

For the past few decades, the issue of corporate governance has dominated much of intellectual debates. The discussions have gained considerable attention due to the trend of governance failure in some firms in both developed and developing markets, like United States, Germany, United Kingdom, India, Malaysia, Indonesia and other parts of the world. This has called for the efficacy of the existing corporate governance structures to protect the interest of stakeholders. Many reforms (i.e. on corporate structures) have been made to ensure that boards of directors are effective in discharging their role (Germain, Galy, \& Lee, 2014). In Malaysia, the Malaysian Code on Corporate Governance (MCCG), was first introduced in March 2000. It sets out the basic principles and best practices of good governance as well as describes optimal corporate governance mechanisms and internal procedures. The code of corporate governance was then revised for several times. These codes are aimed at setting out principles and best practices for firms to use in their operations, in order to attain an optimal governance structure. The codes provide guidelines on several aspects such as size and composition of the board, establishment of risk management committee and the tenure of independent directors. Board monitoring in safeguarding the interests of shareholders is an imperative element of corporate governance (Fama \& Jensen 1983). The board is expected to monitor the decision of the management to decide on beneficial corporate diversification. Moreover, as market control is not active in Malaysia, board governance is expected to serve as sound governance mechanism. Though, in Malaysia, as in other East Asia countries, the effectiveness of the boards may be limited since they themselves are probably controlled by controlling shareholder (Ishak \& Abdul Manaf 2013). Consequently, criticisms have been directed to boards for not always fulfilling their responsibilities and failing in their duty to protect shareholders (Johnson, Daily \& Ellstrand, 1996; Othman \& Rahman, 2010; Zabri, Ahmad \& Wah 2016). 
The core mechanisms of corporate governance are specially designed to overcome the severity of agency problems in modern corporations (Salina \& Nazrul, 2015). Meanwhile, Jensen and Meckling (1976) suggest that agency problems ascend due to the separation of ownership and control which results in a potential clash of interest between owners and managers. Managers who quest for self-interests are doubtful to maximize returns to shareholders as they have a tendency to misuse corporate assets. Through involvement in high risk or imprudent investment to the detriment of capital providers (John \& Senbet, 1998; Salina \& Nazrul, 2015). Though the conflict of interest may decrease firm's value and interfere with corporate investment strategy (Denis \& McConnell, 2003; Ishak \& Abdul Manaf 2013). In accordance, a good corporate structures and procedures are indispensable in order to protect the shareholders' interest and reduce the possibility of loss in firm value due to the separation of ownership and control (Ishak \& Napier 2006; Mollah, Al Farooque \& Karim, 2012; Arora \& Sharma, 2016).

The remainder part of this paper is structured as follows; review of related literature on corporate governance alongside hypotheses development, followed by methodology, then result and discussions. Finally, the paper concludes and provides research limitations and direction for further research.

\section{Literature Review}

In recent years, the issue of corporate governance is gaining significance all over the world (Surya, 2016). However, prior studies on the relationship between corporate governance and firm value produce mixed findings. The first revelation is that, there exist a positive effect of corporate governance on firm value (Renders, Gaeremynck \& Sercu, 2010; Surya, 2016; Khan, Tanveer \& Malik, 2017). While there are prior studies that discovered the existence of a negative correlation between corporate governance and firm value (Hutchinso, 2004; Giroud \& Mueller, 2010; Srivastava, 2015; Huang \& Hillary, 2018). Though, other results generated from the third category revealed that corporate governance has no impact on firm value (Gupta, Chandrasekhar \& Tourani-Rad, 2013; Michelberger, 2016).

However, the existence of conflicting relationship between corporate governance and firm value, will not be far-fetched from the use of different proxies, methodologies, samples, and techniques to gauge the effects of corporate governance on firm value. In addition, most of the prior studies use financial variables (such as, return on asset, earnings per share, return on equity, among others) to measure firm value. Therefore, this study uses excess value to measure firm value in relation to diversification. Most of the research in the area of corporate governance were conducted in developed economies, as rich data is available for these economies where active market for corporate control exists (Michelberger, 2016). There are good reasons to postulate that the effectiveness of corporate governance might be quite different in developed and emerging markets (Saravanan, 2012). Hence, studies on the area of relationship between corporate governance and firm value in the context of emerging nation like Malaysia is essential to get better understanding of the issue.

\subsection{Governance Mechanisms}

Corporate governance mechanisms can be observed from both internal and external perspective (Denis \& McConnell, 2003). The major sources of corporate governance reforms agenda in Malaysia are not far fetch from the MCCG by Finance committee on Corporate Governance, Security Commission and Financial Sector Master Plan, Capital Market Master Plan and Bank Negara Malaysia on the financial sector. The MCCG provides guidelines on the principles and best practices in corporate governance and the direction for the implementation as well as plans the future prospects of corporate governance in Malaysia. Based on the Malaysian code on corporate governance from 2000, 2007, 2012 and 2017 code, the aspects covered by MCCG included composition of board, tenure of independent directors, risk management committees and their mandates and activities.

\subsubsection{Tenure of Independent Director}

There is a large literature concerning the benefits and costs of directors' tenure (Chan, Liu, \& Sun, 2013; Vafeas, 2003). Long tenure tends to increases a director's knowledge of the firm, allowing shareholders' interests is to be better served (Wilson, 2016, Reguera-Alvarado \& Bravo, 2017). Directors' organizational commitment increases in tenure. Longer tenure directors may have high job satisfaction and they are less likely to reverse their job acceptance. Thus, extended directors' tenure can enhance the commitment of directors to fulfill their duties and reduce their turnover. In essence, long-tenure directors 
possess higher commitment and willingness to work better. They also possess greater experience, expertise and reputation which are beneficial to the firm value (Xie, 2014). On the other hand, long board tenure may lead to entrenchment which reduces the effectiveness of independent directors. Long tenure independent directors are more likely to possess a friendly relationship gradually with the management (Vafeas, 2003; Byrd, Cooperman \& Wolfe, 2010). Hence, their independence is likely to be compromised as their tenure increase. The controlling shareholders may possess the incentives to influence the independent directors (Anderson, Mansi, \& Reeb, 2004; Kim, Mauldin \& Patro, 2014; Dikolli, Mayew \& Nanda, 2014). This particularly applies to firms in emerging markets like Malaysia, as firms in these markets possess high ownership concentration and are mostly family-controlled. Hence, based on the discussions provided, the study seeks to test the following hypothesis;

$\mathrm{H}_{1}$ : Tenure of independent directors has positive influence on firm value.

\subsubsection{Risk Management Committee}

Risk management is an important element of corporate governance due to its ability to provide a means of realizing corporate objectives and monitoring the performance of an agent by a principal (McNutt \& Demidenko, 2010). Meanwhile, Gates, Nicolas and Walker (2012) reasoned that the risk management committee monitors the level of risk whilst attempting to maximize returns by advising the board of current risk exposures and future risk strategies. This is in line with MCCG issued by Securities Commission and Bursa Malaysia listing requirements. Likewise, the study of Zhao, Hwang, and Low (2013) considered risk management as consisting of specific efforts that establish a buffer or contingency to absorb economic effects and impose controls that will mitigate the extreme losses of a company. Studies on the link between the risk management committee and performance are inconclusive. Cummings and Patel (2009) noted that risk management and financial activities improve the efficiency and consequently the performance of a firm by reducing costs. Contradicting this, The studies of Ong et al., (2015) and Tufano (1996) found little empirical support for risk management practices as a means of maximizing shareholder value. The study of Tufano (1996) and Aebi, Sabato and Schmid, (2012) discovered that risk management practices of firms, such as hedging to reduce their exposure to risk, are more likely to be related to managerial risk aversion than maximizing shareholder value. In Malaysian context, the study of Yatim (2010), further discovered a strong relationship between the existence of a risk management committee and board structures. Risk management committees have made a significant contribution to ensuring that risks are mitigated effectively, thereby improving firm value. Drawing upon the argument, the hypothesis will be formulated as;

$\mathrm{H}_{2}$ : Risk management committee has positive effect on firm value.

\subsubsection{Board size}

Boards of directors are representatives of the shareholders and other stakeholders of the company. A corporate board is delegated with the task of monitoring the performance, and activities of the top management to ensure they act in the best interests of all the shareholders (Jensen \& Meckling, 1976; Erickson, Reising \& Shin, 2005; Khan, Tanveer \& Malik, 2017). In addition, Ruigrok et al. (2006) suggest that the board has other important roles such as design and implementation of strategy and fostering links between the firm and its external environment. The board is conferred with adequate authorities and responsibilities to act in diligent way. It has to manage and control the management of the company, in order to maximize the value of shareholders. The board of a company is considered as one of the primary internal corporate governance mechanisms (Yasser, Entebang \& Mansor, 2015). A well-constituted board with optimum number of directors can be effective in monitoring the management and driving value enhancement for shareholders. Some researchers, however, have been skeptical about board's ability to mitigate the agency problem and enhance firm value (Erickson, Reising \& Shin, 2005). The number of directors on the board (or board size), therefore, is a critical factor that influences the performance of a company (Lipton \& Lorsch 1992; Salina \& Nazrul, 2015). The board acts on behalf of shareholders and is considered as a major decision-making group. The above views on board size leads us to the following hypothesis;

$\mathrm{H}_{3}$ : Board size has a positive impact on firm value. 


\section{Methodology}

This study involves tracing of data of each component of corporate mechanisms (tenure of independent directors, risk management committee and board size) and firm value for the financial year of 2016 annual accounts and reports of listed diversified PLCs in Malaysia. In the selection of the sample firms from the sector, there was strict adherence to the rule of convenient sampling, which results in 150 diversified PLCs listed on Bursa Malaysia stock exchange. The data was analyzed by employing multivariate regression analysis to explain variation in firm value. This was used to test hypothesis 1, 2 and 3 for the purpose of explaining how the independent variables of the study influences the dependent variable. This study adapts the multivariate function model (Yatim, 2010; Ong et al., 2015; Khan et al., 2017) as follows:

$\mathrm{FV}=\beta_{0}+\beta_{1} \mathrm{TIND}+\beta_{2} \mathrm{RMC}+\beta_{3} \mathrm{BS}+\beta_{4} \mathrm{SIZE}+\beta_{5} \mathrm{AGE}+\beta_{6} \mathrm{LEV}+\mathrm{e}$.

Where: FV=Firm Value; TIND=Tenure of Independent Directors; RMC= Risk Management Committee; BS=Board Size; Size=Firm Size; AGE=Corporate Age; LEV=Leverage; e = error term

\section{Dependent Variable}

The excess value was used as measure of firm value adopted in this study as dependent variable. This variable is also used by previous researchers in their studies of measuring firm value in diversified firms (Ishak \& Napier 2006; Berger \& Ofek 1995). The excess value was measured and computed thus:

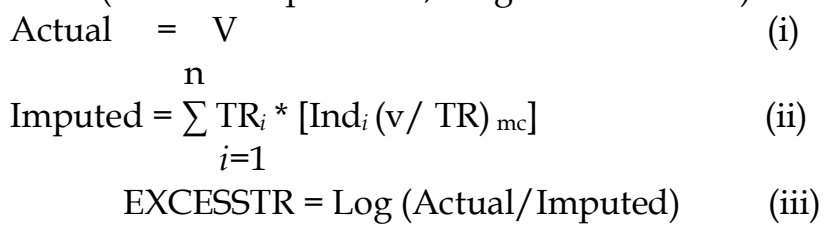

Where; $\mathrm{V}=$ Total capital (book value of debt plus market capitalization) of the Company.

$\mathrm{TR}_{i}=$ Sales of segment $i$

$\left.\operatorname{Ind}_{i}(\mathrm{~V} / \mathrm{TR}) \mathrm{mc}\right)=$ Industry median, total capital to sales ratio

$\mathrm{n}=$ Total number of both three and five -digit segments i's company.

EXCESSTR = Natural logarithm of excess value using sales multiplier.

Independent Variables

Tenure of independent directors, risk management committee and board size are measures of governance mechanisms used in this study as independent variables. These variables were commonly used by previous researchers in their study of corporate governance (McNutt \& Demidenko 2010; Khan et al., 2017). These variables are measured as follows;

Tenure of an Independent Director: Total number of independent directors that serve a tenure of not more than 9 years; Board Size: Total number of directors on the board; Risk Management Committee: A dummy variable of 1 if a firm sets up a risk management committee, 0 if otherwise.

\section{Control Variables}

In addition to examining the relationships between independent and dependent variables in the study, the analyses also controlled certain variables (corporate size, leverage \& age) found by previous researches as have influenced to be playing important role in the proposed relationships. Past studies controlled number of variables suitable to their purpose (Oh, Sohl \& Rugman 2015; Shukla \& Dwivedi, 2016). The variables are measured as; Corporate Size: Natural logarithm of book value of total asset; Corporate Age: Natural logarithm of years since establishment; Leverage: Ratio of total debt divide by equity

\section{Result and Discussion}

As can be seen in Table 1, the average values of the firm value (FV) is 2.98 and the standard deviation is 0.91 indicating lack of substantial variation, that is in line with the study of Ong et al., (2016). In addition, all the explanatory variables also show evidence of lack of substantial variability. The average board size of Malaysian listed diversified companies is between 7 to 8 directors, which is within the size recommended by Lipton and Lorsch (1992), as reported in the study of Salina and Nazrul (2015) for achieving high level of board effectiveness. This is supported by the studies of Mohd Ghazali (2010) and 
Khan et al., (2017). On the other hand, 86 to $69 \%$ of Independent directors Malaysian serve for a cumulative tenure of nine years, as prescribed by the MCCG (2012). The result further revealed that about $57 \%$ of the sampled firm set up a risk management committee.

Table 1: Descriptive Statistics

\begin{tabular}{|l|l|l|l|l|l|}
\hline Variables & Mean & Std. Deviation & Min. & Max & Obs \\
\hline FV & 2.98 & 0.91 & 1.14 & 2.12 & 150 \\
BS & 7.51 & 1.94 & 4 & 14 & 150 \\
TIND & 0.69 & 0.34 & 2 & 4 & 150 \\
RMC & 0.57 & 0.50 & 0 & 1 & 150 \\
\hline
\end{tabular}

Table 2 report the results of the multiple regression analysis for both variables. The result produces an adjusted $R^{2}$ of 0.34, similar to that reported in the study of Vo and Phan (2013). This indicates that the independent variables are able to explain $34 \%$ of the variation in the firm value. The F-statistic shows that the regression model has significance level of 0.00 , which is less than 0.01 . The control variable, corporate size (CSIZE) is significantly related $(p<0.05)$ to firm value, which is similar to (Mohd Ghazali, 2010; Haniffa \& Hudaib, 2006). The result shows that leverage level (LEV) has a significant relationship with firm value at $(p<0.10)$. The result is consistent with the findings of Christensen, Kent and Stewart (2010). However, the result further revealed that corporate age (Age) is not significantly related to firm value. The results of the coefficient as shown in Table 2 shows that both the BS and TIND have negative relationship with FV, this is also in line with the studies (such as, Kim, Mauldin \& Patro, 2014; Dikolli, Mayew \& Nanda, 2014; Srivastava, 2015; Wilson, 2016; Huang \& Hillary, 2018). On the other hand, RMC has a positive relationship with the FV. The finding is in line with the study of Gates, Nicolas and Walker (2012) and Aebi, Sabato and Schmid, (2012). The result supports the earlier predicted hypothesis of the study, that RMC has positive influence on firm value. We check the variance inflation factors (VIF) of our regressions analysis and find that multicollinearity is not a major concern because each of the scores is below the cutting-point 10 (Xie, 2014).

\begin{tabular}{lc} 
Table 2: Regression Result & $\begin{array}{c}\text { Model } \\
\mathrm{t}-\text { statistics } \\
\text { (Coefficient) }\end{array}$ \\
\hline BS & $-3.16^{* *}$ \\
$(-0.27)$ \\
TIND & $-1.81^{*}$ \\
& $(-0.51)$ \\
RMC & $2.23^{*}$ \\
& $(0.34)$ \\
LEV & $1.79^{*}$ \\
& $(0.11)$ \\
AGE & 1.20 \\
& $(0.12)$ \\
CSIZE & $7.09^{* * *}$ \\
& $(0.02)$ \\
R2 & 0.37 \\
Adjusted R & 0.34 \\
Sig. of F change & $0.00^{* * *}$ \\
\hline
\end{tabular}

Notes: ${ }^{*},{ }^{*},{ }^{* *},{ }^{*}=$ p-value $<.10, .05, .01$, respectively, one tailed. The coefficient estimates (number in parenthesis are t-statistic) from the regression result. Abbreviation TIND=Tenure of Independent Directors; RMC= Risk Management Committee; BS=Board Size; Size=Firm Size; AGE=Corporate Age; LEV=Leverage.

\section{Conclusion}

The study investigates the relationship between corporate board structure and the value of diversified firms in Malaysia with multiple segmental reporting. In the light of the summary of the major findings of the study, the study concludes that board size and tenure of independent directors demonstrate a negative relationship with firm value. In addition, the risk management committee maintains a positive relationship with the firm value. The overall outcomes support similar results 
produced by several past studies (Vo \& Phan, 2013; Srivastava, 2015; Wilson, 2016; Huang \& Hillary, 2018), nevertheless conducted in distinct settings.

\section{Research Limitations and Direction for Further Research}

This study was limited to 150 diversified Malaysian public listed companies for only 2016 data. In addition, there are only three indicators used for the independent variables which are board size, tenure of independent directors and risk management committee and firms' value was measured by excess value using the sales multiplier. Different results will be obtained by using other indicators to measure corporate board and firm value. This study can be improved by analyzing a longer time period as longer time period of research may provide more accurate results. Moreover, there are possible numbers of variables that can be used to investigate the determinants of corporate board practices and firm performance. Besides other internal mechanisms of corporate governance such as ownership structure, board meeting, audit committees among others. Future researchers can use external mechanisms as well. On the contrary, excess value using sales multiplier was used to indicate the firm value in the study. There are still other indicators such as assets and Earnings before Interest and Tax (EBIT) multipliers that can also be used to measure excess value.

\section{References}

Aebi, V., Sabato, G., \& Schmid, M. (2012). Risk management, corporate governance, and bank performance in the financial crisis. Journal of Banking \& Finance, 36(12), 3213-3226.

Anderson, R., Mansi, S., \& Reeb, D. (2004). Board characteristics, accounting report integrity, and the cost of debt. Journal of Accounting and Economics, 37(3), 315-342.

Anum Mohd Ghazali, N. (2010). Ownership structure, corporate governance and corporate performance in Malaysia. International Journal of Commerce and Management, 20(2), 109-119.

Arora, A., \& Sharma, C. (2016). Corporate governance and firm performance in developing countries: evidence from India. Corporate governance, 16(2), 420-436.

Bai, G. (2013). How do board size and occupational background of directors influence social performance in forprofit and non-profit organizations? Journal of business ethics, 171-187.

Berger, P., \& Ofek, E. (1995). Diversification' s. Journal of Financial Economics, 37(1), 39-65.

Byrd, J., Cooperman, E. S., \& Wolfe, G. A. (2010). Director tenure and the compensation of bank CEOs. Managerial Finance, 36(2), 86-102.

Chan, A. M. Y., Liu, G., \& Sun, J. (2013). Independent audit committee members' board tenure and audit fees. Accounting \& Finance, 53(4), 1129-1147.

Christensen, J., Kent, P., \& Stewart, J. (2010). Corporate governance and company performance in Australia. Australian Accounting Review, 20(4), 372-386.

Cummings, L., \& Patel, C. (2009). Stakeholder literature review. In Managerial Attitudes of Stakeholder (pp. 17-51).

Dikolli, S. S., Mayew, W. J., \& Nanda, D. (2014). CEO tenure and the performance-turnover relation. Review of accounting studies, 19(1), 281-327.

Denis, D., \& McConnell, J. (2003). International corporate governance. Journal of Financial and, 38(1), 1-36.

Erickson, J., Park, Y. W., Reising, J., \& Shin, H. H. (2005). Board composition and firm value under concentrated ownership: the Canadian evidence. Pacific-Basin Finance Journal, 13(4), 387-410.

Gates, S., Nicolas, J., \& Walker, P. (2012). Enterprise risk management: Management Accounting, 13(3), 28-38.

Germain, L., Galy, N., \& Lee, W. (2014). Corporate governance reform in Malaysia: Board size, independence and monitoring. Journal of Economics and Business, 75, 126-162.

Giroud, X., \& Mueller, H. M. (2010). Does corporate governance matter in competitive industries?. Journal of Financial Economics, 95(3), 312-331.

Gupta, K., Krishnamurti, C., \& Tourani-Rad, A. (2013). Is corporate governance relevant during the financial crisis?. Journal of International Financial Markets, Institutions and Money, 85-110.

Haniffa, R., \& Hudaib, M. (2006). Corporate governance structure and performance of Malaysian listed companies. Journal of Business Finance \& Accounting, 33(7-8), 1034-1062.

Huang, S., \& Hilary, G. (2018). Zombie board: board tenure and firm performance. Journal of Accounting Research.

Hutchinson, M., \& Gul, F. A. (2004). Investment opportunity set, corporate governance practices and firm performance. Journal of corporate finance, 10(4), 595-614.

Ishak, Z., \& Napier, C. (2006). Expropriation of minority interests and corporate diversification in Malaysia. Asian Academy of Management Journal of Accounting and Finance, 2(1), 85-113.

Ishak, Z., \& Abdul Manaf, N. A. (2013). Board of directors and corporate diversification in Malaysia. International Journal of Critical Accounting, 5(2), 123-142. 
Johnson, J., Daily, C., \& Ellstrand, A. (1996a). Boards of directors: A review and research agenda. Journal of Management, 22(3), 409-438.

Jensen, M., \& Meckling, W. (1976). Theory of the firm: Managerial behavior, agency costs and ownership structure. Journal of Financial Economics, 3(4), 305-360.

John, K., \& Senbet, L. (1998). Corporate governance and board effectiveness. Journal of Banking \& Finance, 22, 371-403.

Khan, A., Tanveer, T., \& Malik, U. (2017). An empirical analysis of corporate governance and firm value: Evidence from KSE-100 Index. Accounting, 3(2), 119-130.

Kim, K., Mauldin, E., \& Patro, S. (2014). Outside directors and board advising and monitoring performance. Journal of Accounting and Economics, 57(2), 110-131.

Lipton, M., \& Lorsch, J. W. (1992). A modest proposal for improved corporate governance. The business lawyer, 59-77.

McNutt, P., \& Demidenko, E. (2010). The ethics of enterprise risk management as a key component of corporate governance. International Journal of, 37(10), 802-815.

Michelberger, K. (2016). Corporate Governance Effects on Firm Performance: A Literature Review. Regional Formation and Development Studies, 20(3), 84-95.

Mollah, S., Al Farooque, O., \& Karim, W. (2012). Ownership structure, corporate governance and firm performance: Evidence from an African emerging market. Studies in Economics and Finance, 29(4), 301-319.

Oh, C., Sohl, T., \& Rugman, A. (2015). Regional and product diversification and the performance of retail multinationals. Journal of International Management, 21(3), 220-234.

Ong, T. S., Soh, W. N., Teh, B. H., \& Ng, S. H. (2015). Influence Of Environmental Disclosures On The Financial Performance Of Public Listed Malaysian Manufacturing Companies. Asia-Pacific Management Accounting Journal, 10(1), 107-140.

Othman, Z., \& Rahman, R. A. (2010). Ethics an Malaysian corporate governance practices. International Journal of Business and Social Science, 1(3), 98-109.

Reguera-Alvarado, N., \& Bravo, F. (2017). The effect of independent directors' characteristics on firm performance: Tenure and multiple directorships. Research in International Business and Finance, 41, 590-599.

Renders, A., Gaeremynck, A., \& Sercu, P. (2010). Corporate-governance ratings and company performance: a cross-European study. Corporate Governance: An International Review, 87-106.

Ruigrok, W., Peck, S., Tacheva, S., \& Greve, P. (2006). The determinants and effects of board nomination committees. Journal of Management, 10(2), 119-148.

Salina \& Nazrul. (2015). Corporate Governance and Financial Performance: Empirical Evidence from Public Listed Construction Companies in Malaysia.

Saravanan, P. (2012). Corporate governance and company performance: A study with reference to manufacturing firms in India.

Shukla, D. M., \& Dwivedi, N. (2016). Influence of Board of Directors on Corporate Diversification: Evidence from India. Strategic Change: Briefings in Entrepreneurial Finance, 25(1), 471-484.

Srivastava, N. K. (2015). Does governance structure have any effect on firm performance during the financial crisis: evidence from selected Indian companies. Journal of Strategy and Management, 8(4), 368-383.

Surya Bahadur GC. (2016). Corporate Governance and Firm Performance: Empirical Evidence from India. Journal of Business and Management Research, 1(2), 48-65.

Tufano, P. (1996). Who manages risk? An empirical examination of risk management practices in the gold mining industry. The Journal of Finance, 51(4), 1097-1137.

Vafeas, N. (2003). Length of board tenure and outside director independence. Journal of Business Finance $\mathcal{E}$ Accounting, 30.(7-8), 1043-1064.

Vo, D., \& Phan, T. (2013). Corporate governance and firm performance: empirical evidence from Vietnam. Journal of Economic Development, 7(1), 62-78.

Wilson Jr., T. E. (2016). Director Tenure and Board Meeting Frequency. Southern Business \& Economic Journal, 39(1), 51-65.

Xie, Q. (2014). CEO tenure and ownership mode choice of Chinese firms: The moderating roles of managerial discretion. International Business Review, 23(5), 910-919.

Yasser, Q., Entebang, H., \& Mansor, S. (2015). Corporate governance and firm performance in Pakistan: The case of Karachi Stock Exchange (KSE)-30.

Yatim, P. (2010). Board structures and the establishment of a risk management committee by Malaysian listed firms. Journal of Management \& Governance, 14(1), 17-36.

Zabri, S. M., Ahmad, K., \& Wah, K. K. (2016). Corporate governance practices and firm performance: Evidence from top 100 public listed companies in Malaysia. Procedia Economics and Finance, 35, 287-296.

Zhao, X., Hwang, B., \& Low, S. (2013). Critical success factors for enterprise risk management in Chinese construction companies. Construction Management and, 31(12), 1199-1214. 